\title{
Dronning Eufemia og Eufemiavisene
}

Henriette Mikkelsen Hoel

Da Flores hadde vendt hele riket til Gud, så han seg ut den sterkeste og den modigste, den edleste og den mektigste av hertugene i sitt rike og gav ham Blancheflors mor til ekte. $\mathrm{Nu}$ er hun saktens lykkelig, for nu har Fortuna dreiet på sitt hjul, så hun er kommet til topps!

Langt nede var hun, men snart skulle Fortuna heve henne igjen. Når hun nu ser datteren kronet til dronning og seg selv som hertuginne, takker hun Gud så inderlig ${ }^{109}$

Mange av de skandinaviske dronningene var flerkulturelle med bakgrunn $i$ at de hadde opphav et annet sted enn i det landet de ble dronninger. Da de kom til det nye hjemlandet sitt, kom de til et sted mot nord med annerledes språk og kultur - og de måtte danne seg et nytt nettverk. Dronningene er gode eksempler på kvinner som transnasjonale kulturbærere, og dronning Eufemia er én av dem. Eufemia kom fra fyrstedømmet Rügen, og hun var dermed den første dronningen i Norge med tysk bakgrunn.110 Eufemia er kanskje aller mest kjent for å ha vært oppdragsgiver for oversettelsene av Eufemiavisene til fornsvensk, og ved nærmere ettersyn hadde flere andre dronninger i Norge sterke litterære interesser. Kan i så fall innfallsvinkelen for å få større innblikk i dronningenes rolle være å se på deres forhold til litteratur? Eufemia og hennes litterære interesser blir utgangspunktet for denne artikkelen. Det er lansert flere teser om hvorfor Eufemia fikk oversatt Herr Ivan Løveridderen, Hertug Fredrik av Normandie og Flores og Blancheflor. I denne artikkelen vil jeg argumentere for min tese om at Eufemia fikk oversatt Eufemiavisene for datteren sin, Ingebjørg.

109 Flores og Blancheflor (Oversatt av Olaug Berdal, Oslo 1985).

110 Fyrstedømmet Rügen hadde slavisk opphav, men det ble stadig mer fortysket. 


\section{Hvem var Eufemia av Rügen?}

Eufemia ble født mellom 1275 og 1280, og var datter av fyrst Vitslav II av Rügen og Agnes av Braunschweig-Lüneburg. ${ }^{111}$ Fyrstedømmet hun kom fra lå sentralt ved Østersjøen, og med avtale om giftermål mellom Eufemia og Håkon ble hun en viktig brikke i det politiske spillet som foregikk i kampen om kontroll over Østersjøen og Halland. Eufemia forlot fyrstedømmet Rügen i løpet av vinteren 1299, og hun giftet seg med hertug Håkon i løpet av våren samme år. 13. juli 1299 døde broren til Håkon, kong Eirik II Magnusson. Kong Eirik døde sønneløs, og med det ble Håkon konge av Norge - og Eufemia dronning. Det er ikke mulig å si sikkert nøyaktig dato for kroningen, men trolig ble Håkon og Eufemia kronet i Oslo 1. november 1299. ${ }^{112}$ At Eufemia også ble kronet er en del av det opphøyde synet på dronningen som kom som en følge av den nye kongsideologien; kongen var en rex iustus. Slik som kongen stod over alle andre menn, stod dronningen over alle andre kvinner. Eufemia var dronning i tretten år, fra 1299 og til sin død i 1312. Å føde barn var blant de viktigste oppgavene dronningene hadde, og aller helst skulle de føde sønner. Håkon og Eufemia fikk bare ett barn sammen - datteren Ingebjørg som ble født i 1301. Å få giftet bort Ingebjørg til et medlem av den svenske kongefamilien, var et av de viktigste trekkene for den videre alliansebyggingen som var sentral i kampen om kontroll over Østersjøen. Fremtiden til dronning Eufemias datter lå utvilsomt i Sverige. ${ }^{113} \mathrm{Og}$ slik ble det også; september 1312 giftet Ingebjørg seg med hertug Erik av Sverige.

Eufemia var den første norske dronning med hovedsete i Oslo. For Eufemia kan med rette kalles Oslos middelalderdronning. Hun er den første og eneste dronningen i middelalderen med hovedsete i det som i dag er Norges hovedstad. I hennes tid som dronning ble middelalderborgen på Akershus oppført, og hun er den første dronningen som kan knyttes til

111 Det er blitt diskutert hvorvidt Vitslav II var faren eller morfaren til Eufemia; dette blir også behandlet i min masteroppgave om Eufemia. Denne artikkelen bygger på resultatene fra oppgaven. Se Henriette Mikkelsen Hoel, "Eufemia - fyrstedatteren fra Rügen: En undersøkelse av Eufemias politiske og kulturelle rolle som norsk dronning 1299-1312", Masteroppgave i historie (Universitetet i Oslo 2012); Henriette Mikkelsen Hoel, ”Fyrstedatteren som ble norsk dronning”, i Bjørn Bandlien (red.), Eufemia: Oslos middelalderdronning (Oslo 2012) ss. 35-46; Henriette Mikkelsen Hoel, "Hertig Fredrik av Normandie og arven fra Braunschweig", i Bjørn Bandlien, Eufemia: Oslos middelalderdronning (Oslo 2012) ss. 203-205.

112 Se Hoel (2012) s. 62.

113 Hoel (2012) s. 64 


\section{KVINNOR SOM KULTURBÄRARE}

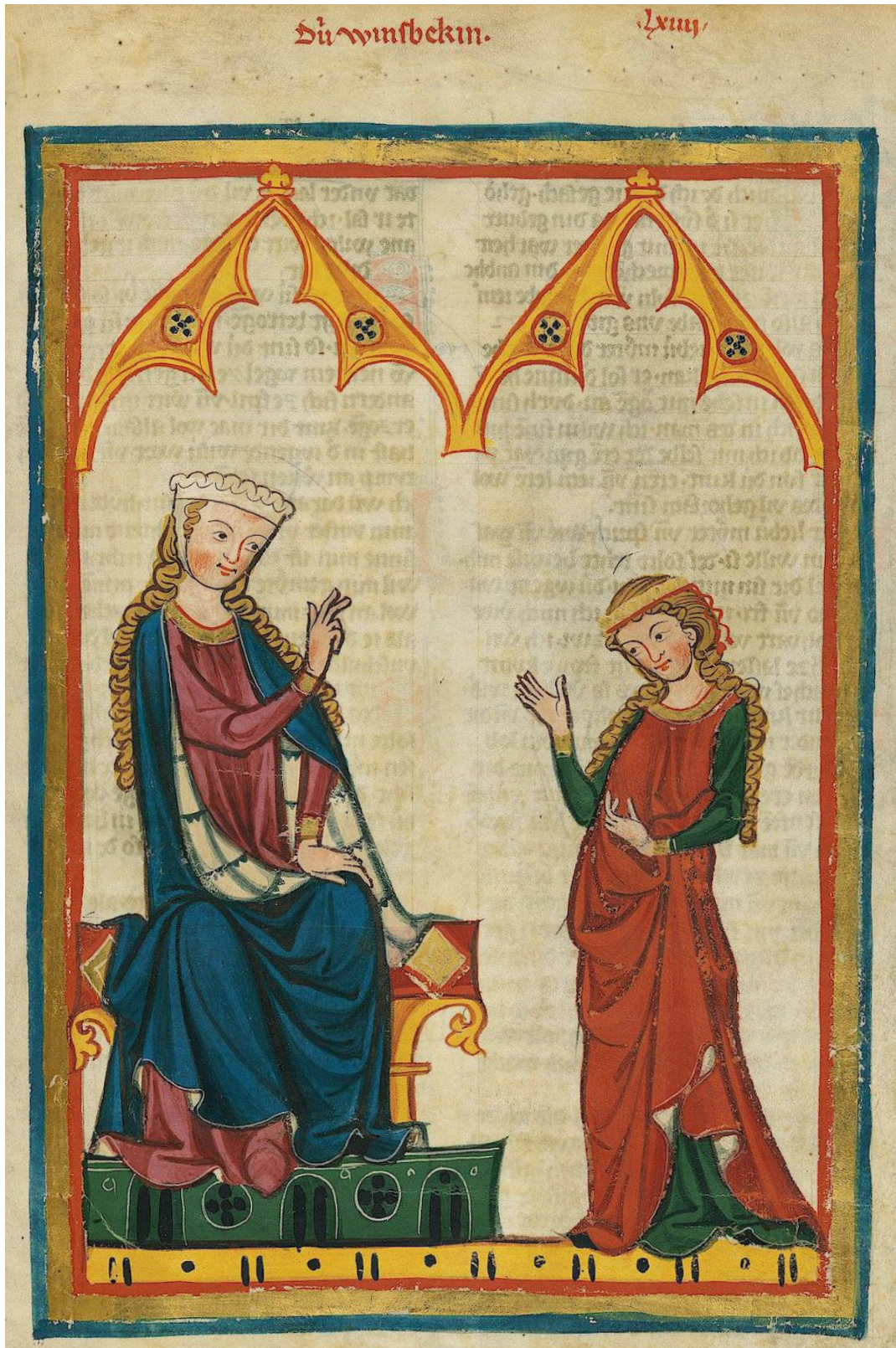

Fruen fra Winsbach fra Codex Manesse: En frue lærer opp datteren sin i høviskhet. 
anlegget. ${ }^{114}$ Med Eufemia fikk den tyske kulturen større innflytelse på det norske hoffet. Selv om det allerede hadde vært tyske handelsfolk i Oslo som hadde tilført deler av sin kultur lenge før Eufemia kom til Oslo, var det naturlig at det var gjennom henne at denne kulturelle innflytelsen ble en del av høviske livet; gjennom hennes virke som dronning kan det tenkes at den tyske kulturen fikk en høyere status. Eufemia kom fra en familie hvor faren, fyrst Vitslav II, kom fra det rygiske fyrstehuset som hadde hersket på Rügen siden den danske erobringen i 1168. Det er blitt gjort påfallende lite undersøkelser om moren til Eufemia, Agnes av Braunschweig-Lüneburg. Hun kom fra det tyske huset Welfen; en mektig fyrstefamilie med medlemmer som Henrik Løve, keiser Otto IV av det tysk-romerske riket og hertug Albrecht av Braunschweig-Lüneburg. ${ }^{115}$

Kildematerialet viser at Eufemia deltok i offentligheten - hun var med på leidangstog mot Danmark og deltok på seremonier. Eufemia var høvisk, gavmild og en dronning med et godt rykte. Og hun var en litterær patron. Eufemia er uløselig knyttet til Eufemiavisene -Herr Ivan Lejonriddaren, Hertig Fredrik av Normandie og Flores och Blanzeflor. Det er gjort flere forsøk på å forklare hvorfor Eufemia skal ha fått oversatt de tre riddersagaene til svensk, og vi skal nå se på de disse.

\section{Ble Eufemiavisene oversatt til hertug Erik?}

Den første som koblet de tre oversettelsene til konkrete historiske hendelser var Peter Andreas Munch i Det norske folks historie. Munch lanserte hypotesen om at oversettelsen av Eufemiavisene ble gjort i forbindelse med det kommende giftermålet mellom hertug Erik av Sverige og prinsesse Ingebjørg. Ifølge Munchs tese ble Herr Ivan Lejonriddaren oversatt i forbindelse med hertug Eriks besøk i Oslo julen 1302 hvor Erik skulle hilse på sin ett år gamle forlovede for første gang. Hovedmotivet for oversettelsen skulle være å hedre hertugen med en oversettelse av en fransk riddersaga.

Sommeren 1307 kom hertug Erik tilbake til Norge, og han ytret ønsket om snarlig inngåelse av giftermål mellom seg og Ingebjørg. Dette sa Håkon $\mathrm{V}$ nei til - en beslutning som førte til dårlig stemning mellom hertug Erik og den norske kongen. Likevel valgte Håkon å støtte hertugen i

114 Hoel (2012) s. 63.

115 Hoel (2012) s. 30. 
konflikten med den danske kongen, Erik Menved. Et brudd kom først sommeren året etter. Munch har koblet oversettelsen av Hertig Fredrik av Normandie til denne fasen; det var ikke brudd mellom partene og det kom fortsatt til å bli bryllup. Eufemia kan ha sørget for en oversettelse for å pleie forholdet til hertugen og nærmest smøre han med tålmodighet.

Videre mente Munch at den siste av Eufemiavisene, Flores och Blanzeflor, ble oversatt i forbindelse med det nært forestående bryllupet. Etter en rekke endringer i avtalene som hadde blitt inngått, endte det likevel med giftermål mellom hertugen og den norske prinsessen i 1312, og Munch foreslo at Eufemia kan ha fått verket oversatt til den anledningen. Munch viste også til Erikskrönikan i forsøket på å finne en sammenheng med oversettelsene, hvor han legger vekt på skildringene av forholdet mellom hertug Erik og dronningen - blant annet at dronningen tok hertugen i mot med "søte ord og rød munn" og at "hun hadde ham i sitt hjerte". ${ }^{116}$ Basert på dette lanserte Munch tesen om at det var et kjærlighetsforhold mellom Eufemia og hertug Erik, og at hennes lidenskapelige forhold til hertugen var årsak til at hun ville overøse ham med gaver - henholdsvis riddersagaer oversatt til hans språk. ${ }^{117}$

I norsk sammenheng har historikerne gått gode for Munchs antagelser når det gjelder motiv for oversettelsene, og få har søkt etter andre motiver enn Eufemias forsøk på å hedre hertugen. I Norsk biografisk leksikon skriver Narve Bjørgo at "det er neppe tvil om at Eufemia var ein romantisk beundrar av hertug Erik”. Bjørgo hevder også at den åpenbare beundringen hun hadde for hertugen, var en sterk medvirkende årsak til oversettelsesarbeidet. ${ }^{118}$ Var motivet for oversettelsene så enkelt? Med utgangspunkt i årstallene 1303 (Herr Ivan Lejonriddaren), 1308 (Hertig Fredrik av Normandie) og 1312 (Flores och Blanzeflor) kan man som Munch anta at det er en kobling mellom oversettelsene og ekteskapsavtalen mellom Ingebjørg og hertug Erik. Oversettelsene kan ha blitt gjort for å pleie forholdet til lille Ingebjørgs kommende ektemann. Samtidig er det altså to manuskripter som opererer med 1300 og 1301 som oversettelsesår for Hertig Fredrik av Normandie. På det tidspunktet forelå det

116 Erikskrönikan, Sven-Bertil Jansson (red.) (Stockholm 1985), s. 91.

117 P.A. Munch, Det norske folks historie, 6. bind. (Christiania 1852-63).

118 Narve Bjørgo, "Eufemia”, i Jon Gunnar Arntzen (red.), Norges konger og dronninger (Oslo 2001), s. 286. 
ingen avtale om ekteskap mellom Ingebjørg og hertug Erik - Ingebjørg ble først født i 1301 - og dersom de respektive årstallene er korrekte, må dermed motivet ha vært et annet. ${ }^{119}$

\section{Høviskhet ikke rettet mot enkeltpersonen hertug Erik, men mot Sverige?}

Flere har altså konkludert med at oversettelsene ble gjort på oppdrag av dronning Eufemia og gitt til hertug Erik - og dette har vært tesen som har blitt stående med bredest aksept blant forskerne. Det er lite hold i den påståtte kjærlighetsaffæren mellom Eufemia og hertug Erik, spesielt siden det bare er Erikskrönikan som ligger til grunn for påstanden. Passasjen hvor dronningen opptrer med både søte ord og rød munn er en del av et velkomstritual - hertugen hilser kongen først, deretter dronningen. Fremfor å avsløre sitrende følelser mellom en norsk dronning og hennes kommende svigersønn, viser den at Eufemia visste hvordan hun skulle utøve høviskhet i sin rolle som dronning når en staselig gjest ankom hoffet.

Samtidig kan det ikke utelukkes at oversettelsen ble gjort på et rent diplomatisk grunnlag, kanskje som en del av alliansebyggingen med Sverige. Kan så ha vært tilfelle, at oversettelsene ble gjort uavhengig av hertug Erik og den konkrete planen om giftermål mellom hertugen og lille Ingebjørg, og iverksatt som en gest for å pleie forholdet til Sverige? Denne gesten kunne i så fall være med på å sikre at når det en gang ble født en norsk prins eller prinsesse, ville det være naturlig at vedkommende fikk en ektemake fra Sverige. Spesielt viktig var det å få en avtale med Sverige siden Danmark allerede hadde sikret seg et slikt bånd med Sverige

119 Thomas Småberg og William Layher har begge tatt for seg Eufemia og henne som oppdragsgiver for å få oversatt de tre verkene. Layher stiller seg ikke uforstående til oversettelse av Hertig Fredrik i 1300/1301, men hevder det er mest sannsynlig at den ble gjort i 1308. Likevel vinkler Layher forskningen sin annerledes enn det som har blitt gjort tidligere, og får slik støtte fra Småberg og Lars Lönnroth. Thomas Småberg, "Bland drottningar och hertigar: Utblickar kring riddarromaner och deras användning i svensk medeltidsforskning", i Historisk Tidskrift, 131/2011, ss. 197-226;

Lars Lönnroth, "Det höviska tilltalet", i Lars Lönnroth, Sven Delblanc (red.), Den svenska litteraturen 1 (Stockholm 1987), ss. 93-123. Layher påpeker viktigheten med å se mer på indre forhold enn bare på de ytre, i tillegg til å hevde at oversettelsene av verk kan ha blitt gjort for å maksimere deres kulturelle verdi for Ingebjørg uten at han gjør noen omfattende analyser for å bygge opp under den påstanden. Layhers innspill gir forskningen som har blitt gjort tidligere et mer nyansert aspekt, og samtidig viser det at også innenfor dette området er det mye ugjort forskning. Se William Layher, Queenship and voice in Northern Europe (New York 2010), ss. 91-130. 


\section{KVINNOR SOM KULTURBÄRARE}

gjennom Ingeborg Magnusdotters ekteskap med Erik Menved i 1296.

Kong Birger var umyndig i denne perioden, og det var Torgils Knutsson som fungerte som formynder fram til Birger nådde myndighetsalder. Det var altså han som styrte riket fram til 1302. Videre fungerte Torgils som marsk, rådgiver og riksråd, og var sentral i styrelsen av Sverige også etter at Birger ble myndig. Dersom oversettelsen ble gjort på et rent diplomatisk grunnlag, kan Torgils Knutsson ha vært en mottager av denne gesten som gjorde at Sverige fikk sitt første høviske litterære verk skrevet på svensk, på knittelvers, og som kanskje også introduserte Sverige for ridderlitteraturen. ${ }^{120}$ Men kan det også tenkes at det ikke var Eufemia som brakte Hertig Fredrik til Sverige for første gang - at verket allerede sirkulerte i svenske kretser på slutten av 1200-tallet, men at Eufemia var oppdragsgiver for å få det oversatt fra tysk til svensk?

Arbeidet til Rasmus Luvigsson (ca 1520-1594) kan lede oss i denne retningen. Rasmus Ludvigsson fungerte som svensk kongelig sekretær, historieskriver og genealog. Hans arbeid innebefatter blant annet oversikt over svenske storslekter i middelalderen, og det danner grunnlag for rådende kunnskap om svensk middelalder også i vår tid. Rasmus Ludvigsson har også omtalt Eufemiavisene i den såkalte Rasmusnotisen. I notatene påpeker han at to av manuskriptene dateres til henholdsvis november 1300 og april 1301. Det interessante med Rasmusnotisen er at han kobler Sveriges første møte med det tyske manuskriptet til Hertig Fredrik av Normandie til 1273, altså før Eufemia ble født omkring 1280.

I 1273 ble det inngått en avtale om giftermål mellom Rikissa Valdemarsdotter av Sverige, datter av Valdemar Birgersson, og en greve av Braunschweig. I den forbindelse ble det sendt en svensk delegasjon til Braunschweig for å diskutere avtalen. Delegasjonen ble utsendt fra Gälakvist i Västergötland, og det var også der den svenske kongen befant seg den sommeren. Den bestod av Dominus Gregorius, uektefødt sønn av Birger jarl, Dominus Petrus, lagmann fra Vestgötaland, Dominus Gudmanus og Dominus Jonas. Det er tidligere blitt gjort forsøk på å identifisere disse mennene, og det er foreslått at Petrus kan være Peter Algotsson. ${ }^{121}$ Da det svenske følget kom til Braunschweig, ble de møtt av

120 Bjarne Beckmann, "Om tiden och sättet för Hertig Fredriks försvenskning", i Arkiv för nordisk filologi 62, (Lund 1947), ss. 263-267.

121 William Layher (2010) s. 94. 


\section{MEDELTIDENS GENUS}

fem av hertugdømmets fremste menn, deriblant fire av Eufemias onkler: Hertug Albrecht av Braunschweig-Lüneburg, Johan, Otto og Konrad.

Hvordan dette oppholdet fortonet seg i detalj, kan ikke sies sikkert. Det man vet, er at avtalen ikke ble noe av. I 1275 ble Valdemar Birgersson slått av broren Magnus (Ladulås) som hadde fått støtte av Erik Menved (etter at Magnus ble konge snudde Erik og støttet Valdemar i stedet), og det ble lagt nye politiske strategier. Rikissa giftet seg med den polske prinsen, og senere kongen, Przemyslaw II av Polen, 11. oktober 1285. Noe man da også følgelig vet, er at delegasjonen fra Sverige oppholdt seg i Braunschweig under besøket der i 1273. Der ble det holdt møter, men sannsynligvis også fest. ${ }^{122}$ Kan delegasjonen fra Sverige i den anledning ha blitt presentert for et av fyrstehusets store epos, og deretter ha brakt det med seg hjem igjen til Sverige? Verket kan ha vært kjent i Sverige på 1290-tallet ${ }^{123}$, og Erikskrönikan kan også fortelle om nær kontakt mellom Sverige og hertugdømmet, blant annet om et besøk av ingen ringere enn hertugen av Braunschweig:
Thaw art i Stokholm howat aff makt,
Swa at manz hierta giorde sakt
Ok mykla gläde hwo thet saa.
Hertogen aff Brunswik war ther tha. ${ }^{124}$

Videre kan den fortelle at som den høviske mann hertugen var, ble han slått til ridder. Erikskrønikan hevder at det i den anledning ble holdt stor

122 Beckmann (1947) ss. 263-267.

123 Bjarne Beckmann har hevdet at verket var velkjent i Sverige på 1290-tallet, spesielt i vestgötske stormannskretser, og flere andre, blant andre Per Wieselgren og Carl Ivar Ståhle, har støttet ham i dette synet (selv om Ståhle mener at Eufemia fikk Eufemiavisene oversatt på grunn av hertug Erik, og støtter seg på P.A. Munchs antagelser). Se Per Wieselgren, ”Hertig Fredriks datering”, i Arkiv för nordisk filologi 62 (1947), ss1-24; Carl Ivar Ståhle, "Till Frågan om tillkomsten av 'Hertig Fredrik"”, i Arkiv för nordisk filologi 64 (Lund 1949) ss. 237-245. Det er også blitt gjort forsøk på å identifisere opphavsmannen til den tyske versjonen som var forelegg for Hertig Fredrik. Kontakten med Braunschweig har gjort at man har tenkt seg at det kan ha vært Berthold von Holle, som virket der ved midten av 1200-tallet, se August Lütjens, ”Herzog Friedrich von der Normandie: ein Beitrag zur Geschichte der deutschen und schwedischen Litteratur des Mittelalters", i Georg D.W. Callwey (red.) Mü̈chner Archiv für Philologie des Mittelalters und der Renaissance 2 (München 1912); Florian Bambeck, Herzog Friedrich von der Normandie: Der altschwedische Ritterroman Hertig (Wiesbaden: Reichert 2009). Layher er mer skeptisk, Layher (2000) ss. 235-236.

124 Erikskrönikan (1985) s. 66. 
fest med både dans og turneringer.

Spørsmålet er om det var innholdet i Hertig Fredrik av Normandie som var kjent, eller om den svenske delegasjonen fikk med seg et manuskript skrevet på tysk fra Braunschweig - eller kanskje Albrecht brakte det med seg under sitt opphold i Sverige? Dersom den svenske delegasjonen fikk med seg et manuskript, finnes det ingen kilder som forteller hva som eventuelt skjedde videre med det. Interessant i denne sammenhengen er imidlertid koblingen mellom et eventuelt manuskript i Vest-Sverige og den norske dronningen som fikk det oversatt.

Både denne mulige koblingen og motivet for en oversettelse i 1300/01 leder oss til leidangstoget i 1300 som Eufemia var en del av, hvor hun antageligvis fulgte i farens fotspor, og var aktiv i en fredsvennlig retning. Forhandlingene endte $\mathrm{i}$ en traktat som ledet til en treårig våpenstillstand mellom Norge og Danmark. ${ }^{125}$ I forbindelse med leidangstoget søkte det norske følget kontakt med svenske stormenn fra Västergötland. Hvis vi fortsatt holder oss til tanken om at Hertig Fredrik av Normandie kan ha blitt brakt til Sverige i forbindelse med møtet i Braunschweig i 1273, kan Eufemia ha blitt presentert for dette manuskriptet i møtet med stormennene. Dette ville ha vært av betydelig interesse for Eufemia, siden hun trolig hadde kjennskap til det store eposet til fyrstefamilien moren hennes var fra, men også siden møtet den svenske delegasjonen hadde hatt i Braunschweig, var blitt ledet av fire av onklene hennes. ${ }^{126} \mathrm{I}$ den forbindelse kan dette ha resultert i et oversettelsesprosjekt fra Eufemias side, hvor et eventuelt motiv kan ha vært at oversettelsen var en gave til en svensk stormann, ikke hertug Erik, men kanskje marsken Torgils Knutsson. ${ }^{127}$

\section{Kan Eufemiavisene ha blitt oversatt for Ingebjørg?}

Mens tidligere forsøk på forklaring av oversettelsene har vært knyttet til hoffet i Sverige og hertug Erik, er det ikke gjort forsøk på å se på om Eufemia kan ha hatt andre motiver for oversettelsen. Kan Eufemia ha fått oversatt ridderlitteratur for Ingebjørg på talespråket i det som skulle bli datterens nye hjemland?

125 RN II 1050; Islandske Annaler, utg. Gustav Storm (1888) s. 72 og 146.

126 Beckmann (1947) ss. 263-267.

127 Beckmann (1947) ss. 263-267. 


\section{MEDELTIDENS GENUS}

Litteraturen har hatt mange funksjoner gjennom tidene - den kan virke opplysende, dannende og underholdende. I middelalderen var den i all hovedsak forbeholdt adelen og det øvre borgerskapet, fordi bøker og manuskripter var dyre. Litteratur forbindes ofte med menn - enten at det er et mannlig overhode i familien som eier den, i tråd med den føydale modellen, eller en munk som skriver. ${ }^{128}$ I den tradisjonelle middelalderforskningen har kvinners forhold til litteratur fătt begrenset oppmerksomhet, men i takt med forskningen på kjønnshistorie er også forholdet mellom kvinner og litteratur blitt viet mer plass de siste tiårene. Kvinners forhold til bøker i Norge har det vært begrenset forskning på, men det har blitt forsket på selve bøkene. I den sammenheng er Margretes tidebok én av bøkene som skiller seg ut.

\section{Dronning Margretes tidebok}

I Berlin finnes det en tidebok skrevet i England på 1200-tallet som har tilhørt dronning Margrete. Margrete Skulesdatter (ca.1210-1270) giftet seg med Håkon IV Håkonsson 25. mai $1225^{129}$ og var datter av jarl Skule Bårdsson - som hevdet rett til den norske kronen. Bryllupet ble arrangert i håp om å skape fred mellom kong Håkon og Skule jarl, men konflikten endte med at Skule ble drept av Håkons menn ved Elgseter kloster i 1240. Håkon IVs tid som konge fra 1240 er preget av indre stabilitet og en offensiv utenrikspolitikk. Som en følge av utenrikspolitikken ble det knyttet sterke bånd med øyene i vest, og det var flere gaveutvekslinger mellom Norge og England; Margrete fikk et kostbart skarlagensklede av den engelske kongen, Henrik III, mellom 1238 og 1240. Margretes tidebok kan også ha blitt gitt direkte til henne av den engelske kongen eller den kan ha blitt gitt til Håkon først og deretter til Margrete. ${ }^{130}$ På de første sidene av boka er dødsdagene til noen av de norske kongene og erkebiskopene oppført. Paleografisk kan disse innførslene dateres til før 1250, og trolig har Margrete fått nedtegnet datoene selv.

Hva skjedde så videre med Margretes tidebok? Margrete selv døde i

128 Susan Groag Bell, i Mary Erler og Maryanne Kowaleski (red.), Women and Power in the Middle Ages (Athens, 1988) s. 149.

129 De ble trolovet seks år tidligere, på Mikkelsmesse 1219.

130 Halvdan Koht antyder i Norske dronningar (Oslo 1926) at tideboken kan ha vært en morgengave fra Håkon IV til Margrete, se side 27-35. 


\section{KVINNOR SOM KULTURBÄRARE}

1270 etter å ha tatt inn på nonneklosteret på Rein tre år tidligere. ${ }^{131}$ Trolig ble tideboken innlemmet som en del av det kongelige hoffs bibliotek før hennes død - tideboken forble i hvert fall hos den norske kongsætten inn på 1300-tallet. Etter Håkon Vs død og personalunionen med Sverige, ble størsteparten av biblioteket flyttet til Båhus fra 1341 til 1346. For det meste rommet det kongelige biblioteket i Båhus lovsamlinger, men der var det også ridderlitteratur, Herr Ivan Lejonriddaren og Hertig Fredrik av Normandie var blant bøkene. ${ }^{132}$ Eufemia, datteren til Ingebjørg Håkonsdatter, giftet seg med hertug Albrecht av Mecklenburg, og hun ble stammor for de oldenborgske kongene. Med inn i ekteskapet fikk også hun med seg bøker, deriblant Margretes tidebok. Slik har tideboken reist fra England som en gave for å pleie vennskapet mellom kongehusene i England og Norge, for så å bli fraktet fra Norge, trolig via Sverige og det kongelige biblioteket der, til Tyskland som en del av gjenstandene en ung brud tok med seg fra det gamle hjemlandet og til det nye.

\section{Bøker - oppdragelse og arv}

Siden kvinner hadde begrenset adgang til det geistlige liv, ble religiøs litteratur desto viktigere. ${ }^{133}$ Det fantes ulike typer bøker som hadde religiøst innehold, men den mest populære boktypen var en "Book of Hours", en tidebok. Dette var en bønnebok som inneholdt tidebønner, bønner som skulle bli lest ved bestemte tider i løpet av dagen. I tillegg inneholdt den gjerne forskjellige samlinger av bibelsk materiale og helgenberetninger. Ofte ble tidebøker gitt som gave til unge jenter som skulle lære å lese, og en tidebok var også en naturlig del av innholdet i brudekisten. ${ }^{134}$ I tidlig middelalder var det først og fremst bøker med religiøst innhold som fulgte med bruden til det nye hjemmet hennes, men fra høymiddelalderen og inn i senmiddelalderen ble det i tillegg til religiøs litteratur vanligere med høvisk litteratur og grammatikkbøker. ${ }^{135}$

Bøker spilte en vesentlig rolle i barneoppdragelsen. Allerede på 300-tal-

131 Margrete ga Rein kloster, som var et kloster faren hennes hadde skipa, en gullkalk i løpet av sin tid der. Kalken ble værende på Rein frem til 1531 da erkebiskop Olav Engelbriktsson tok den og andre gjenstander med seg og rømte landet.

132 Diplomatarium Norvegicum, Bind III, 202 og Regesta Norvegica, Bind V, 318.

133 Bell (1988) s. 160.

134 Bell (1988) s. 175.

135 Bell (1988) s. 176. 


\section{MEDELTIDENS GENUS}

let uttalte Hieronymos, og senere fulgte flere opp hans utsagn, at det var kvinners oppgave å gi barna en moralsk oppdragelse, og det innebar en innføring i den litterære verden. ${ }^{136}$ Mellom 1247 og 1249 baserte Vincent av Beauvais seg på Hieronymos da han på bestilling av dronning Margaret av Provence, gift med kong Ludvig IX, skrev De eruditione filiorum nobilium (om adelkvinners oppdragelse). Denne inneholdt kapitler som dreide seg spesifikt om jenters utdannelse, og en del av verkets budskap er at ved å holde seg opptatt med lesing kunne jenter unnslippe syndige tanker og handlinger, da spesielt seksuelle. I første halvdel av 1300-tallet skrev Francesco di Barberino Reggimento e Costumi di Donna, og her tar han det for gitt at det var moren som skulle stå for barns oppdragelse og første undervisning. Han påpeker videre betydningen av at kvinner skulle lære å lese og skrive, spesielt i tilfelle land skulle tilfalle henne, slik at hun skulle stå bedre rustet til å styre. Han understreker at det er viktig at det er kvinner som oppdrar og underviser kvinner, da situasjoner hvor to personer, særlig da to personer av motsatt kjønn, kommer nær hverandre, gir grobunn for mange onder. ${ }^{137}$

À velge ut lesestoff var en del av tilretteleggingen av undervisningen for unge jenter. Et annet viktig område var å få litteratur oversatt til morsmål. Det meste av religiøs litteratur var skrevet på latin, et språk kvinner sjelden behersket. Vanligvis var det menn som lærte latin som en del av en mulig geistlig fremtid. Likevel var det forventet at kvinner skulle lese denne litteraturen. ${ }^{138}$ Derfor var det ofte kvinner som var pådrivere for å få oversatt litteratur fra latin til morsmål. Dette gjaldt ikke bare religiøs litteratur, men litteratur generelt. Eksempler på kvinner som bestilte oversettelser, er Marie av Champagne, datter av Eleonora av Aquitania, tanten til keiser Otto IV, som bestilte en fransk oversettelse av første Mosebok. Et annet eksempel er Margaret av Provence, som fikk John de Vignai til å oversette Vincent de Beauvais' Speculum Historiale, et verk om verdens historie fra tidenes begynnelse til slutten av 1200-tallet, bestående av om lag 1400 sider. Bestillingen ble gjort nesten samtidig med mannens bestilling av samme verk skrevet på latin.

Når man skal studere kvinners forhold til litteratur i middelalderen

136 Bell (1988) s. 158.

137 Bell (1988) s. 162.

138 Bell (1988) s. 165. 
er bøker som en del av oppdragelsen viktig. Det er også kvinner som arvinger av litteratur og litteratur som medgift. Av testamenter fra 1200- og 1300-tallet fremgår det at kvinner kunne arve menn, men det kommer også frem at kvinner kunne arve andre kvinner. En annen god kilde til kvinners arveforhold i det tyske området på 1200- og 1300-tallet er Sachsenspiegel. Den første boken i Sachsenspiegel tar for seg gjenstander i husholdet som skulle arves av kvinner, og kan fortelle hva som skulle arves fra mor til datter. Det dreide seg da om mindre dyr, senger, enkle møbler, sengetøy, tøy, kjøkkenredskaper - og bøker. Sachsenspiegel ble ofte kopiert gjennom 1200- og 1300-tallet, og den ble også brukt i ikke-saksiske områder, siden lovene hadde bred appell. ${ }^{39}$

Det var også mye på grunn av kvinner at litteraturen, både religiøs og sekulær, spredte seg rundt om i Europa i middelalderen. Kvinner ble giftet bort og fikk gjerne ektemenn som bodde mange mil unna stedet de hadde vokst opp på. Kvinnene var ofte unge, mange fortsatt bare barn når de ble giftet bort, og i varierende grad fikk de med seg medgift. Blant det øvre sjiktet inngikk bøker som en del av medgiften, og ofte bestilte mødre bøker for å gi i bryllupsgave. ${ }^{140}$ Slik kunne litteraturen også fungere som noe trøstende for de unge kvinnene som måtte reise tidlig hjemmefra; de fikk da noe kjent å forholde seg til som kanskje kunne være med på å døyve hjemlengselen. På den måten tok de med seg litteratur fra hjemstedet til sitt nye hjem, og slik fungerte mange kvinner som transnasjonale kulturbærere.

Så langt har vi sett at kvinner hadde et nært forhold til bøker. Kvinner arvet bøker, bøker kunne være en del av medgiften, bøker kunne bli gitt som gaver generelt - noe som var et tegn på høviskhet, bøker var en del av den høviske lære. Og det var mødrene som var sentrale i utvelgelsen av barnas litteratur. Hvordan passer Eufemia og Ingebjørg inn i dette mønsteret? For å svare på det, er det nødvendig å gå tilbake til Eufemias oppvekst på Rügen og moren, Agnes, sin bakgrunn som welfer.

\section{Hva kan Agnes ha brakt med seg til Rügen?}

Hvordan Agnes' oppvekst i Braunschweig-Lüneburg fortonet seg er uviss, men en kilde forteller at hun i 1263 var i klosteret St. Wigbert i Qued-

139 Eike von Repgow, Sachsenspiegel (oversatt av Clausdieter Schott) (Zürich 1984) s. 1.

140 Bell (1988) s. 179. 


\section{MEDELTIDENS GENUS}

linburg. ${ }^{141}$ Villa Quitilingaburg nevnes for første gang i 922 i et offentlig dokument utstedt av Henrik I (med tilnavnet "Fuglefangeren"), og byen Quedlinburg ble grunnlagt i 924 av samme keiser. Fra 900-tallet og inn på 1100-tallet var byen königspfalz - kongsgården i byen var favorittresidensen til de saksiske keiserne i tidsrommet 919-1024. Siden keiserne oppholdte seg her i lengre perioder, ble også Quedlinburg et betydelig kultursentrum. På 900-tallet ble det også bygd en stiftskirke i byen som fikk navnet St. Servatins. ${ }^{142}$ Da Henrik I døde i 936, grunnla kona hans, Mathilde av Ringelheim, en klosterstiftelse i Quedlinburg. Klosteret fikk etter hvert store eiendommer, og blant de største giverne finner vi Otto den store (912-973) som var sønn av Henrik I og Mathilde.

Hvordan kan et opphold i dette klosteret ha preget Agnes? Klosteret St. Wigbert var et såkalt Damenstift, beregnet på kvinner med adelig bakgrunn, og mange av abbedissene som har ledet klosteret kom fra tyske keiserfamilier (mange av dem ble også gravlagt i krypten her). St. Wigbert-klosteret tilhørte premonstratenserordenen. Ordenen ble stiftet i Prémontré i 1120 av St. Norbert, som senere ble erkebiskop av Magdeburg, og godkjent av pave Honorius II i $1126 .{ }^{143}$ Ordenen spredte seg raskt om i Europa, og på midten av 1300-tallet var det 1300 klostre for menn og 400 for kvinner rundt om i Vest-Europa. Premonstratenserordenen etablerte seg sterkt i Tyskland, og de ble viktige i kristningsprosessen av venderne. Ordenen skilte seg fra de andre ved at de i

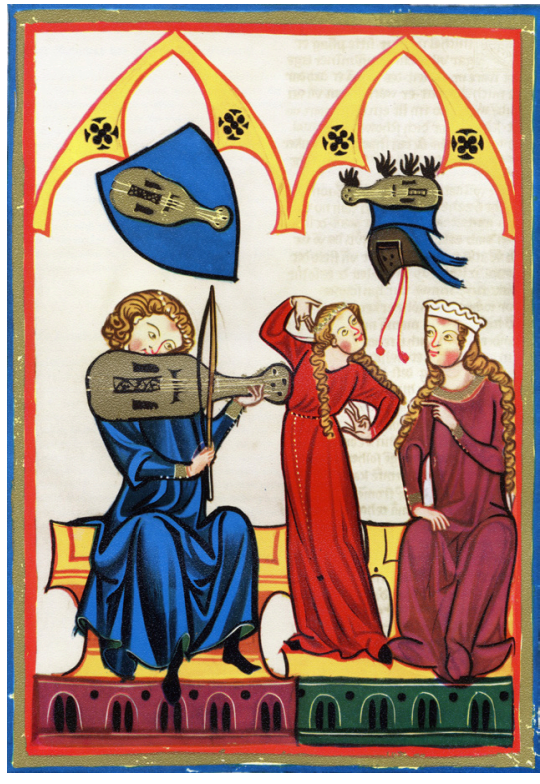

Reinmar der Fiedler fra Codex Manesse: Motivet ser ut til å være en dansetime for en ung kvinne som instrueres av en danselærer - kanskje moren hennes?

141 Antiquitates Quedlinburgenses, Karl F. Kettler (red.) (Leipzig 1712) s. 286/287, nr. 23.

142 Både slottet og stiftskirken er i dag oppført på UNESCOs verdensarvliste.

143 C.H. Lawrence, Medieval Monasticism (Harlow 2001) s. 166. 
større grad likestilte det åndelig liv til kvinner og menn, munker og nonner. Ved flere av klostrene benyttet munkene og nonnene seg av samme kirke, og hadde klostrene sine i nærheten av hverandre. Et eksempel på abbedissenes stilling ved klosteret i Quedlinburg, er at det ble gitt tillatelse til abbedissene selv kunne drive myntpreging fra 944.

Likevel er det tydelige forskjeller fra det nøkterne livet Clairvaux frontet som grunnlegger av cistercienserordenen og tilværelsen i klostrene rundt om i det nordlige Tyskland. Flere av kvinnene som levde i kloster ble tatt opp i regelen de tilhørte og ble nonner. Samtidig var det også kvinner der som fulgte regelen, men som ikke ble nonner - for disse kvinnene ble klosteret en læringsinstitusjon. Og det var nettopp en læringsinstitusjon klosteret i Quedlinburg utviklet seg til å bli - og det til et av de fremste av sitt slag. ${ }^{144}$ Klostrene i Nord-Tyskland skilte seg ut fra mange av de andre klostrene i Europa; de var preget av en større åpenhet som resulterte $i$ at kvinnene som levde her ikke ble isolert fra omverden. De fikk en form for utdanning her som de tok med seg da de forlot klosteret, og det var det Agnes fikk da hun var i kloster tidlig på 1260-tallet, for så å gifte seg med Vitslav II av Rügen.

I det welfiske området var det flere kvinneklostre på 1200-tallet, og en gruppe av disse klostrene i området mellom Lüneburg og Celle har eksistert helt opp til vår tid - de såkalte "Lüneburger Klöster». Dette er seks benediktinske og cistercienske klostre som ble grunnlagt i perioden 900-1200, hvor alle fulgte Benedikts regel, og spesielt klostrene Ebstorf, Lüne, Wienhausen og Medingen har omfattende arkiver som kan fortelle om hvordan livene der har utspilt seg. ${ }^{145}$ Arkivene kan fortelle om et mangfoldig sosialt nettverk gjennom adelens nettverk i Lüneburg og aktiv utveksling mellom klostrene. ${ }^{146} \mathrm{Vi}$ vet at Agnes var i kloster i Quedlinburg, som ligger om lag åtte mil sør for welfernes hovedsete, Braunschweig. Om Agnes kan ha vært i ett av Lüneburgerklostrene først eller om hun kom rett til Quedlinburg kan vi ikke si sikkert i dag, men

144 C.H. Lawrence (2001) s. 219.

145 Benedikt av Nursia (ca 480-550) grunnla en rekke kloster, først og fremst Monte Cassino i

Italia, i tillegg til at han skrev klosterregler som ble grunnleggende for de fleste klostrene, kjent som Benedikts regel.

146 Linda Maria Koldau, "Bibel og liturgi som verdensbilledets fundament: Litteratur, kunst og musik i senmiddelalderlige kvindeklostre", i Ole Høiris og Per Ingesman (red.), Middelalderens verden: Verdensbilledet, tenkningen, rummet og religionen (Århus 2010) ss. 242-225. 


\section{MEDELTIDENS GENUS}

hvordan livet i Lüneburgerklostrene utspilte seg kan tjene som eksempel på hvordan Agnes kan ha hatt det da hun var i Quedlinburg. Å finne seg selv, sin plass i denne verden - og veien til frelse er essensielt i klosterlivet. I det neste avsnittet skal vi se på et konkret eksempel på en welfisk innskriving av seg selv i et eksistensielt verdensbilde, nemlig et kart ved navn "Ebstorfer Weltkarte".

\section{"Ebstorfer Weltkarte" - å skrive seg inn i et verdensbilde}

Ebstorfer Weltkarte er et verdenskart med en diameter på 3,57 meter, og det var sitt største i sitt slag i middelalderen. Det er laget på 30 sammensydde geiteskinn, og det har blitt spekulert i om det var den lærde krønikeskriveren Gervasius av Tilbury som lagde det på 1200-tallet, men i etter tid har det blitt datert til om lag 1300. Jerusalem er sentrum i kartet, og verdens grenser er omfattet av Kristi legeme, hvor hans hode, hender og føtter markerer henholdsvis øst, nord/sør og vest. Verdensbildet er østorientert, og i det nedre venstre hjørne finnes de da kjente kontinentene Asia, Afrika og Europa, og sammen med andre historiske storbyer, finner man en kirke ved navn Ebbekestorp. Byen kirken ligger i kalles i dag Ebstorf, ligger sør for Lüneburg og har i dag om lag 5500 innbyggere. Dette lille tettstedet ble tegnet inn på verdenskartet, noe som tyder på at kartet ble laget i nettopp Ebstorf.

Det var også i kvinneklosteret i Ebstorf kartet ble funnet i 1830. Klosteret i Ebstorf var som klosteret i Quedlinburg et premonstratenserkloster. Da det ble stiftet i 1150 var det et dobbeltstift, men på slutten av 1100-tallet ble det gjort om til et benediktinerkvinnekloster. Om kartet ble tegnet i klosteret kan ikke sies sikkert, men man kan med stor sikkerhet si at det i hvert fall ble laget i welfisk område, siden flere steder i welfisk territorium er detaljert fremstilt, i tillegg til at den welfiske løven også er representert. ${ }^{147}$ En innskriving i et religiøst fundamentert verdensbilde, var en viktig del av middelalderens klosterliv, og nettopp eksistensen var sentral i dagliglivet, og det som ga eksistensen sin sanne mening var tidebønnen og messen. Innskrivingen av Ebstorf i verdenskartet viser denne bevisstheten om eksistens og et fundamentert verdensbilde som også var til stede ved klostrene i Lüneburg-området.

Hvor lenge Agnes var i Quedlinburg kan vi ikke si noe sikkert om i dag 147 Koldau (2010) s. 225. 


\section{KVINNOR SOM KULTURBÄRARE}

- vi vet bare at hun har tilbrakt tid i en av de viktigste læringsinstitusjonene for adelskvinner i det tyske området. Lærdommen og erfaringene fra tiden i kloster tok Agnes med seg da hun flyttet til Rügen. Da Agnes kom til Rügen hadde hun med seg sitt eget følge, og med seg hadde hun også sine egne tradisjoner og sin kulturelle bakgrunn fra Braunschweig-Lüneburg. I forsøket på tegne et tydeligere bilde av Agnes og hva hun kan ha videreført til sine egne barn, er det nødvendig å grave enda dypere ned i familiebakgrunnen hennes.

\section{Et riss av huset Welfens kulturtradisjoner}

Huset Welfen hadde sterke tradisjoner, og blant de fremtredende welferne finner vi Henrik Løve (1129-1195) og keiser Otto IV (1175/761218). I tillegg til å være viktige for welfernes politiske virksomhet, var de også viktige for det kulturelle. Som den første tyske fyrstefamilien til å få nedskrevet sin historie, ble også huset Welfen sentralt for den videre litterære utviklingen i det tyske området i middelalderen. Rolandskvadet

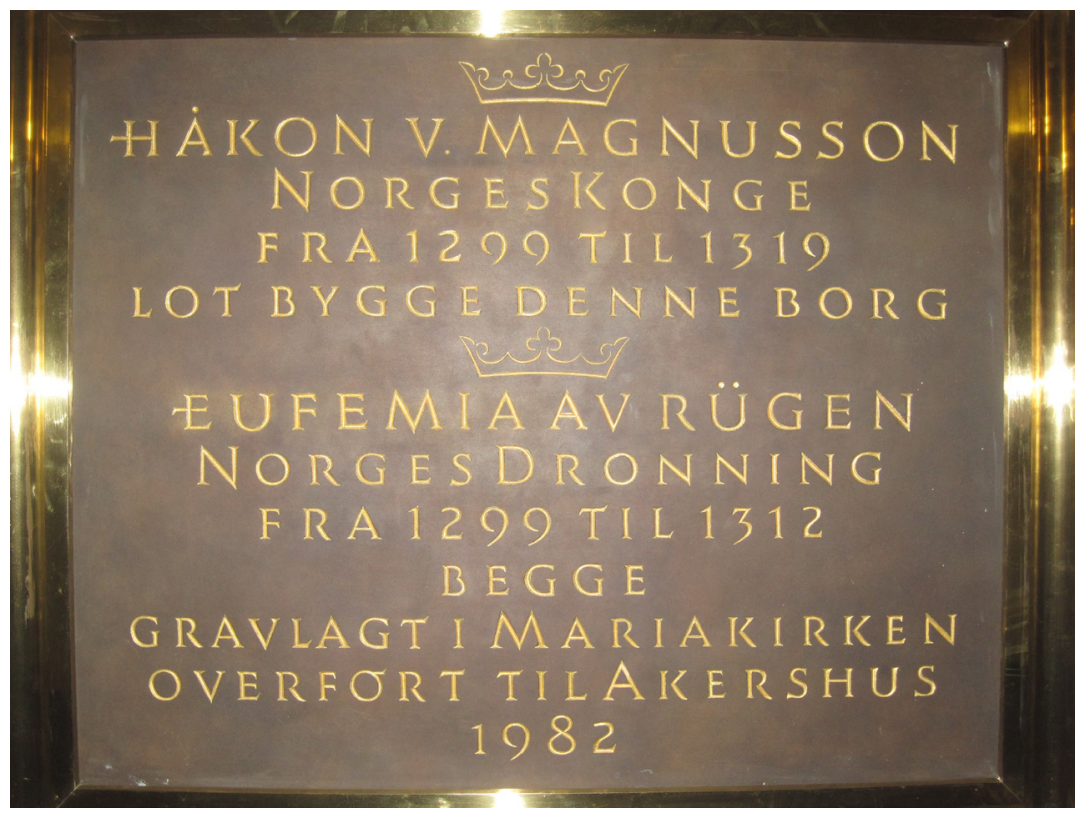

Eufemias endelige gravsted: Eufemia ble opprinnelig gravlagt i Mariakirken i Oslo, men hodeskallen hennes ble overført til krypten vis-à-vis Det kongelige mausoleum på Akershus slott i 1982. 


\section{MEDELTIDENS GENUS}

er det eldste av de franske storverkene fra middelalderen, og handler om Karl den store og de tolv kjempene hans, deriblant Roland. Blant flere andre franske verk ble også Rolandskvadet oversatt til tysk i løpet av middelalderen, og den tyske oversettelsen kan fortelle at det ble oversatt på oppdrag av Henrik Løve etter Mathilde av Englands ønsker: ”Des gerte di edele herzoginne/aines richen chüniges barn" ${ }^{148}$ Et annet eksempel er Henrik Løves Evangeliarium, som ble laget i 1180-årene av munken Herimann ved Hemarshausen kloster. Boken viser kroningen av hertug Henrik Løve og hertuginne Mathilde, og den er med på å gi et inntrykk av Løves syn på eget virke og hans store ambisjoner. ${ }^{149}$.

Otto IV var viktig for utviklingen av Braunschweig, både politisk og kulturelt, men i denne sammenhengen er det det litterære aspektet som er mest interessant. Med det nære forholdet Otto hadde til onkelen, Rikard Løvehjerte, knyttet han seg også til mormoren, Eleonora av Aquitania (ca 1122-1204). Hun var datter av Vilhelm X, hertug av Aquitania og greve av Poitou, og Aénor de Châtellerault. Da faren døde, overtok Eleonora som hertuginne og grevinne, noe som gjorde henne til den mest ettertraktede kvinnen i Europa. Hun giftet seg to ganger; først med kong Ludvig VII av Frankrike, som hun fulgte på korstog, og så Henrik II av England (konge fra 1154). Ekteskapet med Ludvig varte fra 1137 til 1152, og det førte til to barn - Alix de Blois (1151-1198) og Marie de Champagne (1145-1198). Ekteskapet endte uten sønner. Det var den viktigste faktoren til at ekteskapet ble annullert selv om selve annulleringen ble begrunnet med blodsslektskap i fjerde ledd. Med seg ut av ekteskapet fikk Eleonora gods og riker hun hadde brakt med seg inn i det - hertugdømmet Aquitania og grevskapet Poitou. Bare seks uker etter at ekteskapet med Ludvig VII var over, giftet Eleonora seg med Henrik II av England - på det tidspunktet hertug av Normandie og greve av Anjou. Ekteskapet med Henrik førte til flere døtre, men også sønner - Vilhelm, Henrik (den yngre), Mathilda, Rikard I Løvehjerte, Geoffrey, Leonora, Johanna og Johan (uten land).

Ekteskapet med den tolv år yngre Henrik var preget av konflikter, og da datteren Mathilda giftet seg med welferen Henrik Løve i 1167, dro

148 Das Rolandslied des Pfaffen Konrad, Dieter Kartschocke (red.), (Frankfurt am Main 1970) s. 390.

149 Boken blir i dag oppbevart i Wolfenbüttel, ikke langt fra Braunschweig. 
Eleonora fra England og tilbake til Poitou. Eleonora var en av middelalderens sterkeste og mest innflytelsesrike kvinner, men slik som med Otto IV, er det hennes kulturelle geskjefter som er mest interessante i denne sammenheng. Eleonoras farfar var Vilhelm IX (1071-1126), den første kjente trubadur. Han skrev under navnet "greve av Poitou" (som var en del av tittelen hans), og elleve av sangene hans er bevart. Tematikken i sangene varierer fra politikk til kvinner, kjærlighet og seksualitet. Sønnen hans - og dermed Eleonoras far, Vilhelm X, videreførte trubadurarven fra faren, og la sin elsk på trubadurkunsten og litteratur. Han vektla også å videreføre lidenskapen for dette til døtrene sine, og Eleonora fulgte opp arven fra faren og farfaren. I hennes tid i Poitou blomstret både det litterære miljøet og trubadurmiljøet, og virksomheten på hennes tid satte spor etter seg som har vart helt til vår tid. Hun var beskytter for blant annet Wace, Benoît de Sainte-Maure og Chrétien de Troyes - forfatteren av verket Yvain Løveridderen, som Eufemia fikk oversatt til svensk i 1303. Eleonora videreførte igjen sin kulturelle virksomhet til barna sine; Rikard Løvehjerte var selv godt bevandret i trubadurmiljøet i tillegg til å dikte selv, og datteren Marie de Champagne fra ekteskapet med Ludvig VII, skapte som moren et litterært sentrum. ${ }^{150}$

Mens Otto IV oppholdt seg i Poitou var han en del av dette miljøet, og han må ha blitt godt kjent med litteraturen og trubadurtradisjonen som var gjeldende både i England og i Frankrike. ${ }^{151} \mathrm{Og}$ akkurat som onkelen, Rikard Løvehjerte, og mormoren, Eleonora av Aquitania, hadde Otto et godt ord på seg blant trubadurene i Poitou. I 1209 skrev Monge de Montaudon en tenzone til Otto IV som fortsatt er bevart. ${ }^{152}$ Også moren til Otto, Mathilde, ble det diktet til. Bertrand de Born dedikerte to sanger til Mathilde, hvor han dikter om hennes skjønnhet og om hennes rolle som moren til "de l'emperador Oth". ${ }^{153}$

Dette kan ha vært betydningsfullt for ham da han senere ble keiser og skulle fungere som patron og oppdragsgiver for tyske diktere. Braunschweig utviklet seg nemlig som et litterært sentrum under keiser

150 For Eleonora av Aquitanias bakgrunn, se Bonnie Wheeler og John Carmi Parsons, Elenor of Aquitaine: Lord and Lady (New York 2002).

151 Bernd Ulrich Hucker, Otto IV (Hannover 1990) s. 20.

152 Hans virkelige navn var Pèire de Vic, og han var benediktinermunk fra Aurillac fra om lag

1180 til 1210; Hucker (1990) s. 20.

153 Hucker (1990) s. 20. 


\section{MEDELTIDENS GENUS}

Otto IV, en prosess også broren Vilhelm tok del i. Litteratur fra nabolandene ble oversatt og brakt til huset Welfens eie. Denne generasjonens welfere fikk utbygd et betydelig bibliotek - og oversettelsesprosjekter var en del av denne utbyggingen. ${ }^{154}$ Epilogen til Hertig Fredrik av Normandie lyder slik:

Denne bok som I nu har hørt, lot keiser Otto nedskrive og oversette fra fransk til tysk mål; Gud se i nåde til denne fyrstes noble sjel! Nu er boken oversatt for annen gang og nylig satt i rim fra tysk til svensk tunge, for at både unge og gamle kan forstå den. Det var dronning Eufemia som lot boken vende til vårt mål; Gud give hennes sjel evig frelse blant englene i himmerik for alle de gode gjerninger hun gjorde mens hun var her på jorden, til Guds og denne verdens ære! $!^{155}$

Kan det være keiser Otto IV epilogen viser til? Det er vanskelig for oss i dag å fastslå hvorvidt det var keiser Otto IV som stod ansvarlig for oversettelsen, men verket tilhører Arthur-tradisjonen, og helten beveger seg i et franskkeltisk land, i likhet med mange av verkene til Chrétien de Troyes. Verket har også øvrige likheter med de Troyes’ verk, og det er ikke usannsynlig at det skriver seg fra krets de Troyes var en del av. ${ }^{156} \mathrm{Vi}$ vet at Otto IV og hele hans familie var opptatt av litterær virksomhet ved sitt hoff, og oversettelser til tysk var en sentral del av dette. Agnes, Eufemia og Ingebjørg var i slekt med denne keiseren, den eneste keiseren av Det tysk-romerske riket med navnet Otto i det aktuelle tidsrommet - Otto III døde i 1002. Figur 2.

\section{Den litterære patronen Eufemia}

Kildene som omtaler Eufemia direkte er få, og de er krevende. Likevel mener jeg det lar seg gjøre å danne seg et bilde av Eufemias bakgrunn. I denne artikkelen har jeg valgt å trekke frem Eufemias forhold til Eufe-

154 Hucker (1990) s. 19.

155 Hertug Fredrik av Normandie, Olaug Berdal (oversetter) (Oslo1998) s. 119.

156 Joachim Bumke, Courtly Culture (Woodstock, NY 2000) s. 88. 
miavisene, og plassert henne i et større bilde ved å knytte sammen mor, datter og mormor - Ingebjørg, Eufemia og Agnes. Hvorfor er dette perspektivet så viktig?

Munchs teser omkring Eufemiavisene er blitt adaptert av de fleste historikere, litteraturvitere og filologer opp til våre dager. I diskusjonen rundt Hertig Fredriks oversettelse avfeide Carl Ivar Ståhle forslagene om alternative forklaringer til visenes oversettelser; "det må være som P.A. Munch hevdet, oversettelsene ble gjort for hertug Erik". ${ }^{157}$ Men må det være slik? Slik jeg ser det tok P.A. Munch for lett på undersøkelsene om motiv for oversettelsene av Eufemiavisene. I motsetning til Munch, og de som støtter hans teser, mener jeg at det er for enkelt å forklare oversettelsene med Eufemias påståtte følelser for sin kommende svigersønn. At Eufemia fikk oversatt Eufemiavisene for Ingebjørg med tanke på hennes fremtid i Sverige er mer sannsynlig enn at hun gjorde det som en lettsindig dronning for å smigre en listig hertug.

Kvinner som litterære patroner i norsk sammenheng er en uutforsket mark, og det gjenstår derfor mye forskningsarbeid. Eufemia kan ha brukt oversettelsene som et diplomatisk virkemiddel for å pleie forholdet til Sverige hvor hertug Erik var en del av hoffet. Som et resultat ville Norge og Sverige da få en felles hoffkultur. Vel så sannsynlig mener jeg det er at Eufemia ha fătt oversatt visene for Ingebjørg siden hennes fremtid lå i Sverige.

Eufemias rolle som litterær patron da hun fikk oversatt de tre riddersagaene, markerer en ny retning i det litterære Skandinavia. Sverige ble med dette beriket med ridderlitteratur skrevet på fornsvensk. Samtidig ble knittelvers tatt i bruk, noe som også var nytt i norsk sammenheng. Eufemiavisene kan i Norge knyttes til utviklingen av balladene og folkevisene, og slik kan Eufemia mer enn noen annen symbolisere en av mange historiske prosesser der impulser fra utlandet ble tatt opp i norsk kultur. Når vi ser på tradisjonene for kvinner som litterære patroner, taler de for at det er sannsynlig at welfiske Agnes kan ha fătt med seg Hertug Fredrik av Normandie sammen med andre bøker i brudekisten sin da hun giftet seg med Vitslav II. Antageligvis videreførte også Agnes mye av det hun hadde lært i løpet av oppveksten i Braunschweig til sine egne barn på Rügen, og da det ble gjort avtale om giftermål mellom Håkon og Eufe-

157 Ståhle (1949) ss. 237-245. 


\section{MEDELTIDENS GENUS}

mia, fikk Eufemia med sin egen brudekiste som trolig inneholdt bøker av ulikt slag. Én av disse kan ha vært Hertig Fredrik av Normandie. Eufemia kan igjen ha valgt å få oversatt flere riddersagaer til talespråket i det som skulle bli datterens nye hjemland; lille Ingebjørgs fremtid lå i Sverige, noe som lå i skjebnen hennes fra hun knapt kunne gå. 